\title{
Orbital Metastasis as Primary Clinical Manifestation of Thyroid Carcinoma - Case Report and Literature Review
}

\begin{abstract}
Capillary thyroid carcinoma (PTC) is the most common neoplasm of thyroid. It usually grows slowly and is clinically indolent, although rare, its aggressive forms with local invasion or distant metastases can occur. Metastatic thyroid carcinoma rarely involves the orbit. We reported an uncommon case of orbital metastasis of PTC. A 66-years-old woman presented proptosis of the right eye. The biopsy of the tumor in orbit revealed metastatic thyroid carcinoma. The ultrasensitive TSH level was $1,34 \mathrm{mUI} / \mathrm{L}$ and free T4 level was 1,65 $\mathrm{ng} / \mathrm{dL}$. A total thyroidectomy was performed and histopathological analysis of the nodule revealed follicular variant of papillary thyroid carcinoma. Currently, the patient has been receiving palliative chemotherapy with Clodronate Disodium. The importance of the case is due to its unusual presentation, which emerged as a primary clinical manifestation. Although rare, thyroid carcinoma should be suspected in orbit metastasis. (Arq Bras Endocrinol Metab 2008; 52/9:1497-1500)
\end{abstract}

Keywords: Papillary thyroid carcinoma; Orbital metastasis

\section{RESUMO}

Metástase Orbital como Manifestação Clínica Primária de Carcinoma de Tireóide - Relato de Caso e Revisão de Literatura.

Carcinoma papilífero da tiróide (PTC) é a neoplasia mais comum da tiróide. Geralmente cresce lentamente e é clinicamente indolente, embora raras, as formas agressivas com invasão local ou metástases distantes podem ocorrer. Carcinoma metastático da tiróide raramente envolve a órbita. Relatamos um caso raro de metástase orbital de PTC. Uma mulher de 66 anos apresentou proptose no olho direito. A biópsia do tumor em órbita revelou carcinoma metastático da tiróide. O nível ultra-sensível do TSH foi de 1,34 mUI/L e T4 livre foi de 1,65 ng/dL. A tireoidectomia total foi realizada e a análise histopatológica do nódulo revelou carcinoma papilífero variante folicular da tiróide. Atualmente, a paciente recebe quimioterapia paliativa com clodronato dissódico. A importância do caso é devido à sua apresentação incomum que surgiu como principal manifestação clínica. Embora raro, o carcinoma da tiróide deve ser pensado em metástase orbitária. (Arq Bras Endocrinol Metab 2008; 52/9:1497-1500)

Descritores: Carcinoma papilífero da tireóide; Metástase orbitária

\section{INTRODUCTION}

apillary thyroid carcinoma (PTC) is the most common neoplasm of the thyroid ( 1 ). Incidence is increasing, with a global estimate of half a million new cases in 2005 (2). PTC is found in a variety of morphologic variants, like follicular variant of papillary thyroid carcinoma (FVPTC). It usually grows clinical case report

\author{
FrancIsco Dário Rocha FILHO \\ Gabrielle GuRgel LIMA \\ Francisco V. de Almeida FerReira \\ Michelle Gurgel Lima \\ Miguel N. Hissa
}

Instituto do Câncer do Ceará (FDRF, FVAF); Universidade

Federal do Ceará (GGL, MGL, $\mathrm{MNH)}$ ); Fortaleza, CE, Brasil. 
slowly and is clinically indolent, although rare, its aggressive forms with local invasion or distant metastases can occur (2). A minority of patients may present, or subsequently develop, locoregional and distant metastases that may adversely affect survival (3). Besides locoregional lymph nodes, PTC most commonly affects lungs and bones (4).

FVPTC, whether invasive or not, behaves like usual PTC with multiple tumor foci in the gland in many cases, lymphatic invasion and nodal metastases and rare hematogenous spread (5). Survival rates for FVPTC (at least in the short-term follow-up data available) seem to be similar to usual PTC (6). Although true follicular thyroid carcinoma is known to metastasize via the bloodstream and give rise to bone and lung metastases, such a pattern of spread is rare in papillary thyroid carcinoma. The FVPTC is believed to behave in a clinical manner similar to usual or classical papillary cancer and to follow a similar indolent course. There have been a few reports of "aggressive" FVPTC wherein follicular patterned tumors with nuclear features of papillary carcinoma have metastasized hematogenously; these neoplasms have been diffusely invasive or multicentric in the thyroid (7). Metastatic thyroid carcinoma rarely involves the orbit (8). They constitute 5\% to 6.5\% (9) of the total orbital neoplasms. Rarely thyroid carcinoma has to be considered as a potential primary tumor in a patient with an orbital metastasis (10). Recently we had the opportunity to evaluate a patient in whom we found a metastatic lesion in the orbit from a primary thyroid carcinoma (FVPTC). This founding led us to review the literature for a survey of the incidence of metastatic thyroid carcinoma to the orbit. In this paper we describe a patient with PTC who initially presented right orbit mass.

\section{SUBJECTS AND METHODS}

\section{Case Report}

A 66-years-old woman came to the hospital with a history of unilateral proptosis on the right eye for one year. On physical examination we noticed that the right eye was dislocated inferiorly, but did not affect the visual acuity. Thyroid was palpable during the swallow with a nodule on the right lobe. Ultrasonography revealed an increased right lobe with two hypoecogenic lesions. The superior lesion measured $2.72 \times 2.60 \times 2.12 \mathrm{~cm}$. The second lesion measured $2.2 \times 1.79 \times 1.09 \mathrm{~cm}$. The orbit computed tomographic scan (CT) showed an expansive solid tumor projected to the upperside of the right orbit on the lacrimal gland topography, associated to the frontal bone mass with superficial intracranial invasion and bone damage at the lateral wall with approximately $45 \mathrm{~mm}$ at the main axis. The figures 1 and 2 show the axial and coronal CT scan. She was submitted to surgery in the right orbit with mass biopsy procedure. The tumor anatomopathology exam showed sections with thyroid follicle cover with uniform cuboid epithelial full of colloids and delimitated by fibroid pseudo-capsule. The fine-needle aspiration cytology revealed two solid nodes in the right lobe with follicular cells proliferation, leukocytes, fibrocytes and citodetritos. The ultrasensitive TSH levels were $1.34 \mathrm{mUI} / \mathrm{L}$ and $0.9 \mathrm{mUI} / \mathrm{L}$ and free T4 level was $1.65 \mathrm{ng} / \mathrm{dL}$. The patient was submitted to total thyroidectomy. The macroscopic exam revealed a right thyroid lobe that measured $5.3 \times 3.7 \times 3.0 \mathrm{~cm}$. Within the right lobe, there were two solid nodules. The superior nodule was larger, measuring $2.7 \times 2.5 \times 2.5 \mathrm{~cm}$, and encapsulated. The microscopy exam on the right lobe and small nodules showed epithelium heterotype formed by cells in ground glass and nuclear crank distribution mostly solid and slicly papillar area, indicating papillary thyroid carcinoma (figure 3 ). The orbit immunohistochemistry revealed positivity for HBME 1, cytokeratin 19 (CK19) (figure 4), Galectin-3 (Gal-3) and thyroid transcription factor 1 (TTFl). The patient developed thoracic and lumbar column pain, bone curvature in right supra-orbitary and right fronto-temporal regions. Consolidation with radiotherapy of the right orbit was performed (Total of $3750 \mathrm{cGy}$ ). The patient was submitted to a ${ }^{131}$ I whole-body scan $(4 \mathrm{mCi})$ that showed focis of uptake in the following regions: cerebral, right retro-orbital, coxo-femural and dorso-vertebral. The bone scintigraphy showed radio contrast hypercaptation in the right orbit and thoracic vertebrae (T3 and T8 to $\mathrm{T} 10)$, indicating secondary process. At this time, the serum thyroglobulin level was $550 \mathrm{ng} / \mathrm{mL}$ (immunometric assay) and antithyroglobulin antibody level was $2.2 \mathrm{IU} / \mathrm{mL}$ (quimioluminescence assay). Currently, the patient is undergoing chemotherapy with Clodronate Disodium with palliative care finality.

\section{DISCUSSION}

The orbit and globe are not in the list of the common sites for metastatic thyroid carcinoma. Reports of inci- 


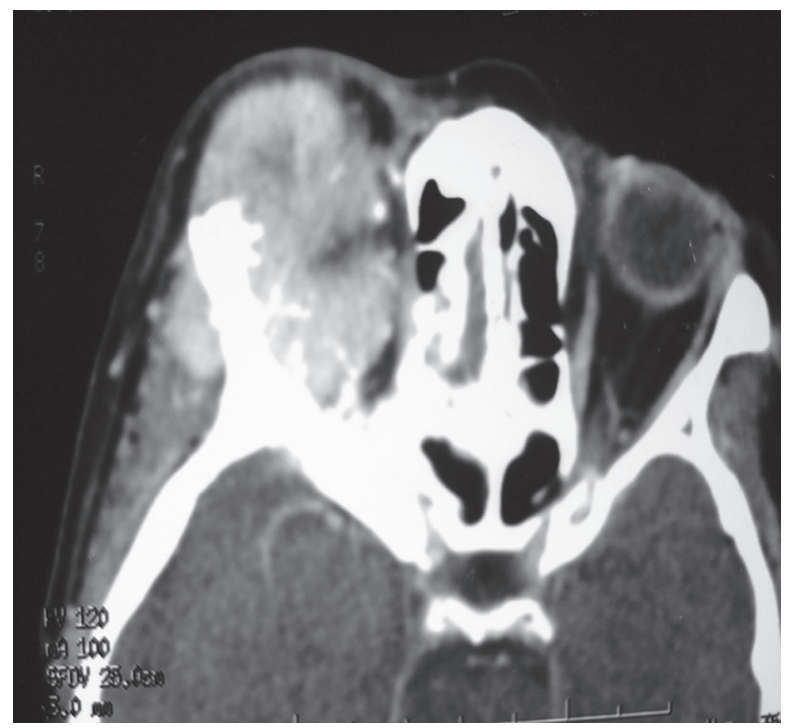

Figura 1. Axial CT scan.

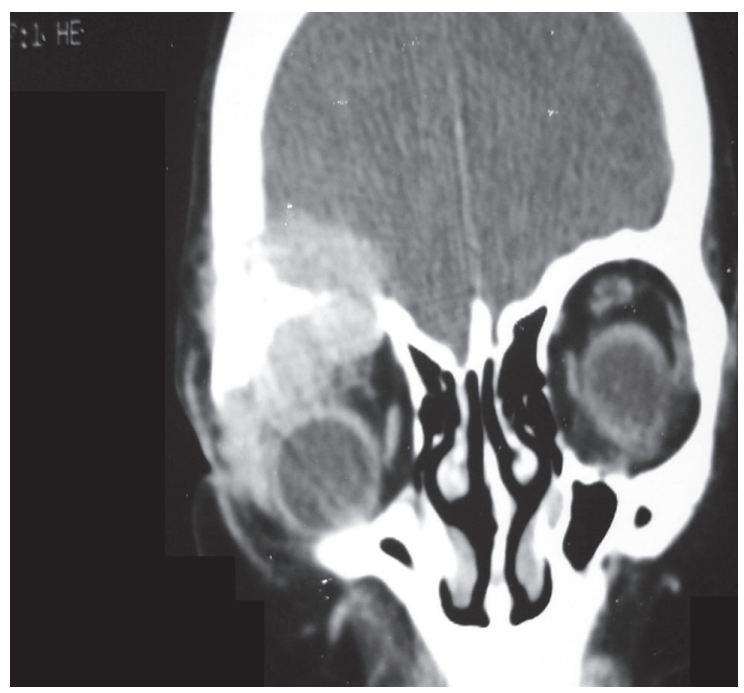

Figura 2. Coronal CT scan showing soft tissue supero-medially in right orbit and sclerotic expansion of the orbital roof.

dence are variable. Hart and Rose point out that metastases to the globe and orbit are relatively infrequent. A survey of 213 patients with primary tumors disclosed 10 patients who had eye or orbital metastases, an incidence of $4-7 \%$, which the authors though suggested more frequent metastasis than previously shown (11). Bloch and Gartner studied 230 patients with known systemic carcinoma regardless of clinical evidence of orbital or ocular involvement and found 28 eyes with eye/ orbital metastases, a $12 \%$ incidence (12). There is gene-

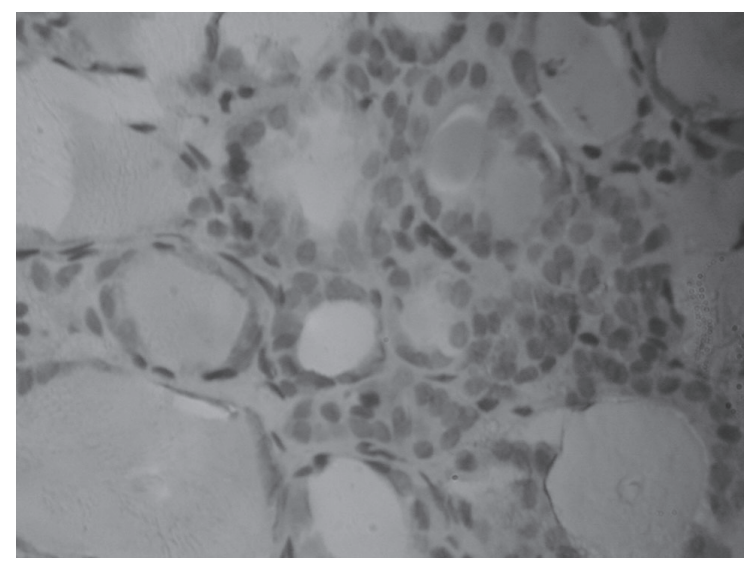

Figura 3. HE (400x)

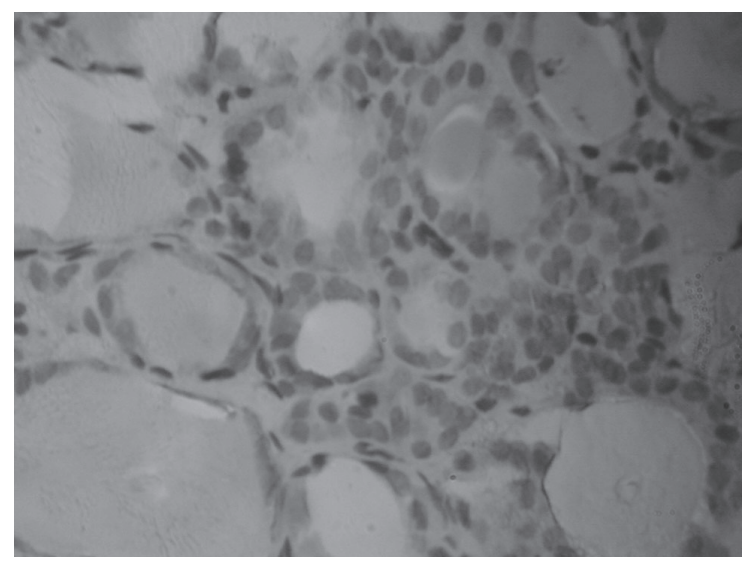

Figura 4. orbit imunohistochemistry: CK19 positive.

ral agreement that among primary malignancies the ones most commonly found to metastasize to the eye or orbit are from the breast and lung (13). The incidence of presentation with distant metastatic disease increases in patients over 45 years of age (14). Rarely, the presence of distant metastasis may be the only initial manifestation of thyroid cancer without clinically apparent disease in the thyroid region (2). In recent years, the therapeutic approaches to patients presenting distant thyroid metastasis are essentially well defined. These include total thyroidectomy if the primary thyroid tumor can easily be resected, followed by radioactive iodine therapy and suppressive treatment with L-thyroxine (14).

The differential diagnosis of encapsulated follicular patterned lesions of the thyroid includes follicular adenoma, follicular carcinoma, and follicular variant 
of papillary thyroid carcinoma (FVPTC). All of these lesions exhibit similar clinical presentations and gross morphology (15). Lindsay (16) first coined the term FVPTC, reporting the detailed morphologic description of this tumor. It has been shown that the majority of these lesions behave similarly to classic PTC (5).

Papillary thyroid carcinoma and its variants can be difficult to distinguish from cellular adenomatous nodules. Nasr et al (17) evaluated immunohistochemical markers in the diagnosis and differential diagnosis of papillary thyroid carcinoma. These findings suggest that the combination of HBMEl and CK19 has the greatest diagnostic utility in the differentiation of PTC from its benign mimics (17). Focal CK19 staining may be found in benign lesions, but diffuse positivity is a characteristic of PTC. HBME-1 positivity indicates malignancy but not papillary differentiation (18). Immunohistochemical stains of CK19, Gal-3 and HBME-1, especially when used in combination, can be an important adjunct to the histopathological diagnoses of thyroid lesions (19).

The scarcity of cases in literature with this localization and morphology confirm the rarity of the case. The related case shows the importance of the immunohistochemistry to strengthen the malignant character of the metastatic tumor.

\section{CONCLUSION}

PTC generally has good prognosis, even with metastasis to locoregional lymph nodes. However, sometimes its metastasis may spread to distant regions, affecting lungs, liver and bones, worsening the prognosis. In such situations, occasionally, the distant metastasis is responsible for the first clinical evidence of the disease. Metastatic lesion of the orbit is relatively rare and is predominately from breast and lung. We found that metastasis from thyroid to the orbit is distinctly rare.

No potencial conflict of interest relevant to this article was reported.

\section{REFERENCES}

1. Podnos YD, Smith DD, Wagman LD, Ellenhorn JD. Survival in patients with papillary thyroid cancer is not affected by the use of radioactive isotope. J Surg Oncol. 2007;96(1):3-7.
2. Sheils O. Molecular classification and biomarker discovery in papillary thyroid carcinoma. Expert Rev Mol Diagn. 2005;5 (6):927-46.

3. Pelizzo MR, Boschin IM, Toniato A, Piotto A, Pagetta C, Gross $M D$, et al. Papillary thyroid carcinoma: 35-year outcome and prognostic factors in 1858 patients. Clin Nucl Med. 2007;32 (6):440-4.

4. Yousuf $K$, Archibald SD. Brain metastases from papillary adenocarcinoma of the thyroid. J Otolaryngol. 2006;35(6):366-72.

5. Evans HL. Follicular neoplasms of the thyroid. A study of 44 cases followed for a minimum of 10 years, with emphasis on differential diagnosis. Cancer 1984;54:535-40.

6. Passler C, Prager G, Scheuba C, Niederle BE, Kaserer K, Zettinig G, Niederle B. Follicular Variant of Papillary Thyroid Carcinoma: A Long-term Follow-up. Arch Surg. 2003;138:1362-6.

7. Baloch ZW, LiVolsi VA. Encapsulated follicular variant of papillary thyroid carcinoma with bone metastases. Mod Pathol 2000;13(8):861-865.

8. Hornblass A, Kass LG, Reich R. Thyroid carcinoma metastatic to the orbit. Ophthalmology. 1987;94(8):1004-7.

9. 9. Betharia SM. Metastatic orbital carcinoma of thyroid. Indian J Ophthalmol. 1985;33(3):191-3.

10. Daumerie C, De Potter P, Godfraind C, Rahier J, Jamar F, Squifflet JP. Orbital metastasis as primary manifestation of thyroid carcinoma. Thyroid. 2000;10(2):189-92.

11. Albert DM, Rubenstein RA, Scheie HG. Tumor metastasis to the eye. I. Incidence in 213 adult patients with generalized malignancy. Am J Ophthalmol. 1967;63(4):723-6.

12. Bloch RS, Gartner S. The incidence of ocular metastatic carcinoma. Arch Ophthalmol. 1971;85(6):673-5.

13. Hart WM. Metastatic carcinoma of the eye and orbit. Int Ophthalmol Clin. 1962;2:465-82.

14. Shaha AR, Shah JP, Loree TR. Differentiated thyroid cancer presenting initially with distant metastasis. Am J Surg. 1997; 174(5):474-6.

15. Hawk WA, Hazard JB. The many appearances of papillary carcinoma of the thyroid. Cleve Clin Q. 1976;43(4):207-15.

16. Lindsay S. Carcinoma of the Thyroid Gland: a Clinical and Pathologic Study of 293 Patients at the University of California Hospital. Springfield, IL: Charles C Thomas; 1960

17. Nasr MR, Mukhopadhyay S, Zhang S, Katzenstein AL. Immunohistochemical markers in diagnosis of papillary thyroid carcinoma: Utility of HBME1 combined with CK19 immunostaining. Mod Pathol. 2006;19(12):1631-7.

18. Cheung CC, Ezzat S, Freeman JL, Rosen IB, Asa SL. Immunohistochemical Diagnosis of Papillary Thyroid Carcinoma. Mod Pathol. 2001;14(4):338-342.

19. Teng XD, Wang LJ, Yao HT, Li J, Ding W, Yan LP. Expression of cytokeratin 19, galectin-3 and HBME-1 in thyroid lesions and their differential diagnoses. Zhonghua Bing Li Xue Za Zhi. 2004;33(3):212-6

\section{Correspondence to:}

Gabrielle Gurgel Lima

Universidade Federal do Ceará

Rua monsenhor Furtado 1438/ 101-103, Rodolfo Teófilo

60430-350 Fortaleza CE

E-mail: gabi_gurgel@yahoo.com.br 